\title{
Socio-Economic Dynamics of Street Vendors in Bandung
}

\author{
Rina Hermawati \\ Department of Anthropology \\ Universitas Padjadjaran \\ Bandung, Indonesia \\ rina.antrop@gmail.com
}

\author{
Nunung Runiawati \\ Department of Public Administration \\ Universitas Padjadjaran \\ Bandung, Indonesia \\ n.runiawati@unpad.ac.id
}

\begin{abstract}
The presence of street vendors has become a hard problem to solve in some cities in Indonesia. Some existing policies have not yet been able to optimally handle the problem of street vendors. One of the causes why the problem of street vendors is hard to handle is unavailability of sufficient data on street vendors. As a result, policies on street vendors are often not on target. This article attempts to map socio-economic characteristics of street vendors in Bandung. By understanding socio-economic characteristics of street vendors, it is expected that the government will be able to map the real problem related to street vendors, so that an appropriate solution to deal with it can be obtained. The result of the research showed that the education level, earnings, and the business typology of street vendors are increasingly varying. If previously street vendors were often considered small scale business and identical to the urban poor groups, nowadays we also find street vendors who come from highly-educated circles, with big capital, big earnings, and modern business means like motorcycles and cars. Likewise, consumers of street vendors have been spread among the middle classes through high quality products with quite a high price (hundreds of thousands to millions of rupiahs). This finding indicates that the profession of the street vendor is not only made as the means to earn the livelihood/to meet the basic needs but also as a strategy to develop the business of the owners of capital and goods.
\end{abstract}

Keywords: business typology; socio-economic characteristics; street vendors

\section{INTRODUCTION}

The informal sector is a general symptom appears all over the world, particularly in developing countries. The existence of the informal sector is often linked to the problems of urbanization, unemployment, and poverty [1]; [2].

BPS data in 2017 mentions about 58.35 percent or 72.67 million Indonesians work in the informal sector. Among various occupations in the informal sector, the one with the most dominant and prominent activities is the street vendors. The presence of street vendors, in quite a large number, has dominated the fulfillment of the needs of the lower-middle class. Besides that, the street vendor is a business type of the informal sector which is often touched by the policies of the city government [2].

Some cities that experience a progressive growth of street vendors are Bandung, Surabaya, and Jakarta [3]. The number of street vendors usually increases prior to the Ramadan and the school holidays. In addition, the unavailability of Corresponding author: Rina Hermawati complete, up-to-date and consistent data of street vendor has resulted in the city government not knowing exactly how many street vendors, who they are, and not also understanding how the life-system is lived by street vendors. As the result, the government is difficult to define what the real problems which are associated with street vendors as well as appropriate and effective solutions to address the problem of street vendors. The unavailability of the data and information has also made some local governments tend to underestimate the presence of street vendors and it makes the policies not on target. Therefore, this article would map socio-characteristics of street vendors in order that it becomes the base for the making of policies on street vendors.

\section{RESEARCH METHOD}

This research applied the quantitative method aiming to map the socio-economic characteristics of street vendors in Bandung. The researchers conducted a survey on 100 street vendors located at the red zone. The process of sample drawing was conducted by using the technique of stratified random sampling through two stages (two stage cluster sampling), namely:

1. Conducting the first stage random to determine the number of street vendors in Bandung which became the sample study area.

2. Conducting the second stage random to determine the number of street vendors who became the respondents of each region which became the sample study area.

\section{RESULT AND DISCUSSION}

\section{A. Socio-Economic Characteristics of Street Vendors in Bandung}

Social characteristics of street vendors in Bandung would be mapped based on sex, age, education level, and reason for becoming street vendors.

The occupation as street vendors is dominated by the males. In 2015 the data of Bappeda (Local Development Planning Agency) of Bandung found that $76.21 \%$ of street vendors were males and $23.79 \%$ were females [3]. The high number of the males among the street vendors is because it is a high-risk occupation. Characteristics of street vendors that occupy public places make them directly face the policies of the city government on the cleanliness, orderliness, and 
beauty of the city. As a result, street vendors become one of the targets of eviction conducted by the city government. In confronting the eviction, men are considered to have the ability to run and move with more agility compared to women. This condition has become one of the factors which cause the business of street vendors is considered more appropriate for men.

Based on the age, the majority of street vendors were still at the age of $15-54$ years, constituting $91.89 \%$, the proportion of street vendors under the age of 15 years was $0,44 \%$, and $8.06 \%$ of them were above 55 years [4]. This distribution of street vendors based on their ages indicates that although the number was low, there were underage street vendors (under 15 years) and the elderly (above 55 years). The underage and elderly street vendors admitted that they earned their living by selling goods to meet their economic needs. The underage street vendors felt obliged to help their parents earn their living. Meanwhile, among the elderly street vendors, the obligation to meet the needs of their families was the reason for still working.

Based on the education level, it has been found that $3.15 \%$ of the street vendors did not graduate elementary school, $27.90 \%$ of them graduated elementary school, $35.70 \%$ of them graduated junior high school, $31.70 \%$ of them graduated high school, and $1.55 \%$ of them had diploma and undergraduate degrees [4]. The data indicates that street vendors, that so far are described as the occupation of uneducated people or those who had low education, nowadays have attracted the interest of the people with higher education. Informants of the research stated that street vendors with higher education have started to emerge since the monetary crisis of 1998 which had caused many cases of layoff and difficulties in seeking for jobs in the formal and informal sectors. Some laid off employees made use of their severance pay for starting their business as street vendors.

\section{B. Regions of Origin of Street Vendors}

The presence of street vendors, which is often linked to the problem of urbanization as found in some studies (such as Manning and Tadjuddin, [1]; Rachbini and Hamid, [2]; Ramli, [5]), is still relevant in elaborating characteristics of the street vendors in Bandung. It appears in the large number of street vendors originating from the migrant group, which was $42.42 \%$, and the rest $57.58 \%$ were from Bandung.

These migrants came from both Java Island, such as Jakarta, Garut, Tasikmalaya, Ciamis, Bandung Regency, and West Bandung Regency and outside Java Island, such as Padang, Palembang, and Medan. It clearly appears that weekly and monthly street vendors operating at the Gasibu are dominated by the migrants, with a variety of products they sell by using a variety of means of business.

The interest of the migrants to make Bandung as their destination is based on the conviction that the earnings promised in Bandung is larger than the income they earn in their place of origin, as answered by $36.09 \%$ of the respondents, followed by the reason that Bandung is a strategic city $(35.78 \%)$, and Bandung is a lively place with many visitors $(24.22 \%)$.

\section{Reasons for Becoming Street Vendors}

The result of interviews with street vendors and association of street vendors indicates that the reason mostly put forth when they were asked why they chose the profession of street vendors was because they were forced to do so as there was no other job. Becoming a street vendor is their last choice when other sectors cannot provide them with a job. Nevertheless, the street vendors admitted that they enjoyed their profession because they were comfortable with the large earnings and free working time.

Related to the free working time, they themselves can choose their operating time and free time so that we can find some street vendors operate only during certain hours or certain days. As for their income, they get daily profit which of course is different from employees who receive monthly salary. The profit earned by street vendors at certain times and locations may exceed the income of employees in the formal sector (further discussed in the subchapter on the income of street vendors).

The second reason for choosing the profession as street vendors is the impact of layoff. Among those who were laid off, some of them made use of their severance pay for starting their own business. Such as selling foods they produce by themselves, vegetables, meat, et cetera. Some enter the sector of street vendors as a temporary choice while they wait for a new job, but some of them have decided to be a street vendor because they have felt 'the comfort" of being a street vendor.

The third reason is to develop the spirit of entrepreneurship. Some street vendor admitted that they have chosen the job because they do not like to work in companies or to work for other people. For them, it is better to run their own business than to depend on others. With a little skill and limited capital, the most appropriate choice is to be a street vendor.

\section{Wares and Financing}

Culinary business was still the most interesting one among the street vendors in Bandung, with as many as $59.05 \%$ of them were interested in the business, followed by fashion products by $14.84 \%$ of street vendors, and other products. As for other categories, they included motorcycles, CDs, tires, and other. The price of the product varied, from thousands to millions of rupiahs. For example, at Jalan ABC watches were sold at the price of Rp15,000 to above Rp1,000,000.

The origin of the products can be distinguished into personal made products/products of home industries and products of medium/big industries. It is important to know the characteristics of street vendors because many of them are no more than the extension of medium and big scale industries and even global scale industries [8]. The research result shows that many street vendors in Bandung are the extension of the industry sector. The Civil Service Police Unit of Bandung have recorded that this type of street vendors is easily found at the Gasibu. These street vendors come from various regions; both residents of Bandung and regions outside Bandung who 
purposely mobilize their business at the Gasibu and even some of them are the formal sector selling a variety of products, such as motor vehicles, accessory products, clothes, CDs and others. Besides that, there are also employees asked by their shops/factories to sell their products at the street as part of the marketing to get close up to the consumers. In this case they adopt the system of street vendors that it is better to approach the consumers before they come to the sellers. The profit is shared on a commission basis.

Besides following the principle of street vendors in selling goods, that is approaching the consumers, the Special Taskforce Unit for Street Vendors assume many formal sectors mobilize their trade at streets in order to evade tax charged by the government. It has been confirmed by the finding of the survey conducted the Office of Cooperatives, Small and Medium Enterprises, Industries, and Trade which stated that many street vendors, if viewed from their sales, actually belong to the category of permanent sellers that have had particular places for selling their goods or places at markets. However, they prefer to be street vendors to evade some regulations of the government, particularly stipulations about taxes.

The existence of street vendors who constitute the extension of industrialists is quite annoying for the "true" street vendors. The "true" street vendors consider the street vendors constituting the extension of industrialists to be their competitors and greedy persons. However, they admitted to be resigned to the situation and believed that their fortune is managed by God.

By mapping the products and the origin of products sold by street vendors, the linkage between the street vendors and the informal and formal sectors can be found out. This linkage clearly appears in the case of the sales of newspaper, cigarettes, and drinks whose marketing distribution depends on the street vendors. However, the informal sellers are not considered to be part of the company. It means they do not obtain standard wage or social and health security which usually are provided for the employees. They even must take some risks of their job which is not stable and often considered to be "illegal" [9]. These dependent vendors get their profit from the difference between the buying and selling prices of the goods they sell.

Most of street vendors (53.06\%) operated every day, $33.48 \%$ of them preferred to take a break on Sundays, and the rest operated only on Saturdays-Sundays or only on Sundays. As for the working hours, street vendors had no certain working hours and some of them tended to work exceeding the standard of working hours stipulated by the government for formal workers, namely 8 hours a day. The working hours were adjusted to the activities around the location where they operated. Street vendors operating around a market usually sold their wares between 01.00- 06.00 West Indonesia Time, street vendors operating around a modern shopping center usually sold their goods between 17.00-22.00 West Indonesia Time, while street vendors operating around a campus and a park usually had a longer working hours, around 09.0017.00 West Indonesia Time.
One of financial aspects needed by street vendors in running their business is the availability of the business capital. On average, business capital required to start the business of street vending was about 1 million to above 5 million rupiahs, which was needed by $66 \%$ of them, less than 1 million rupiahs was needed by $15 \%$ of street vendors and above 5 million rupiahs was needed by $19 \%$ of them.

The data indicates that street vending is still an informal business which is relatively easy to enter if it is related to the small capital needed to start the business. This business capital may be the vendors' own personal money, or lent from families or moneylenders. Among the three sources, moneylenders are the most popular among street vendors. Moneylenders' service is usually used by independent street vendors to start their business, to add their business capital, and to prepare for financial hardships due to sickness and education. Meanwhile, street vendors of "sales for commission" and "dependent jobs" usually need the moneylenders' service only when they have financial hardships due to sickness and education.

The existence of moneylenders cannot be separated from the difficulty faced by street vendors in accessing the informal financial sources (friends/relatives) or the formal ones (banks and cooperatives). Besides that, the easy procedure offered by moneylenders becomes an attractive factor for street vendors to use their service. Compared to formal financial institutions, lending money from moneylenders does not need administrative requirements such as identity cards, approval from husbands/wives, and others therefore it can be said that moneylenders are the most practical "banks" for street vendors.

The average daily net income earned by street vendors

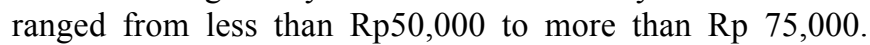
However, some street vendors earned a daily net income of $\mathrm{Rp} 250,000$. The data shows that the income level of street vendors is getting more varying, from less than $\mathrm{Rp} 3,000,000$ a month to more than $\operatorname{Rp~7,500,000~a~month,~hence~the~}$ business of street vending nowadays is not only identical to the urban poor group but also the middle classes.

The data on the average net income of street vendors in 2014 affirms the research conducted by Setia [10] that stated that in general the average income earned by street vendors was sufficient to cover their daily needs and even some of them could earn the income far above the regional minimum pay (UMR) of Rp 2,310,000.

However, their income is usually not stable because it depends on some factors, among others, the location of operation, seasons (rainy or dry seasons, school vacation or not) and activities of the formal sector/other activities around them. For example, during school vacation street vendors usually make an increasing income.

\section{E. Means of Business}

Based on the means of business, characteristics of street vendors in Bandung shows that the majority of street vendors $(41.2 \%)$ used the pushcart and only $4.27 \%$ of them used yokes. Other means used by street vendors were semipermanent tents, tables, kiosks, and mats. 
Other means of business includes cars. Cars have been often used as the means of business since 2007 with foods and clothes as the main products being sold. However, since 2013 some street vendors have started to use cars for selling fruit. They can be found at almost all main streets in Bandung. The street vendors choose cars as the means of business as one of the ways to enable them "escape" from the Civil Service Police Unit while being pursued.

\section{J. Charge Fees}

Although street vending is considered to be illegal/unofficial business, in running their business street vendors are not free from levies/charge fees, both those that use tickets (collected by the local government) and no tickets (collected by hoodlums). The charge fee varied, between $<$ $\mathrm{Rp5,000}$ to $>\mathrm{Rp} 10,000$ a day. Apart from the charge fee, $23.77 \%$ of street vendors admitted that they paid other fees for security, parking, and electricity/lamps. Meanwhile, the rest $71.38 \%$ of street vendors stated that they did not pay any other levies [5].

Therefore, the presence of street vendors has invited "new jobs" for some parties in the form of the practice of protection compensated with unofficial charges. However, some ways they take do not fully guarantee the continuation of their business, particularly when the apparatus from the city government evict the street vendors because the informal "charge collectors" have no legal authority to manage public places. When the eviction occurs, those charge collectors (nongovernment) usually help the street vendors to put up resistance. However, they do it for retaining their source of income rather than protecting street vendors. Besides that, this problem of charges has allegedly caused the conflict of interest among the apparatus of the government so that the eviction they conduct is sometimes discriminating. Some street vendors suspect some certain regions are rarely evicted because their "payment" is larger compared to other regions.

The economic problem (monetary crisis and rare job opportunities) and urbanization are still relevant factors to explain the growing number of street vendors in Bandung. It appears in the high number of street vendors coming from other regions and the increase in the number of street vendors after the 1998 economic crisis. This phenomenon indicates that the studies that relate street vendors and manpower are still relevant to explain the problem of street vendors.

Viewed from the socio-economic characteristics of street vendors, it appears that education level, earnings, and the business typology of street vendors are getting more varying. If previously street vendors were often considered small scale business and identical to the urban poor groups [10];[11];[12], nowadays we also find street vendors who come from highlyeducated circles (high school and university), with big capital, big earnings, and modern business means like motorcycles and cars. Likewise, consumers of street vendors have been spread among the middle classes through high quality products with quite a high price (hundreds of thousands to millions rupiahs). This finding indicates that the profession of the street vendor is not only made as the means to earn the livelihood/to meet the basic needs but also as a strategy to develop the business of the owners of capital and goods. Therefore, if street vendors are mapped based on their turnover, there are categories of "true" street vendors, independent street vendors who make their living depend on the earnings of street vending, and "businessman" street vendors, those who have a turnover exceeding the criteria of small enterprises.

Based on the data, the problem of street vendors cannot be handled with a uniformed policy. Street vendors with small business capital and a low business turnover need some protection in order that they are able to develop their business, such as capital aid, soft loans, and skill improvement. Meanwhile, street vendors with a high turnover should be transformed into traders of the informal sector.

\section{CONCLUSIONS}

The problems of street vendors in Bandung could not be solved by using the normative and top down approach. However, the policy of street vendors is ideally tailored to the characteristics street vendors. Referring to the characteristics of street vendors in Bandung, then there is a shift characteristic of street vendors who is originally only dominated by the bottom class but now is also be cultivated by the middle class. In addition, the facilities and goods which are traded more diverse with varying prices. Other characteristics are influenced by the type of street vendors as independent street vendors, depends on the extension of the employer's hand, and so on. This characteristic difference ideally produces the category of street vendors so it is clear which street vendors need protection and are allowed to sell and which are transferred into the informal sector (having kiosks in markets, malls, etc.).

\section{REFERENCES}

[1] C. Manning \& T.N Effendi. Unemployment and the urban informal Sector (Urbanisasi, (Pengangguran dan Sektor Informal Perkotaan). Jakarta: Yayasan Obor Indonesia. 1991

[2] D.J Rachbini \& A. Hamid. The Urban Informal Symtomps Innovation in the second waves.( Ekonomi Informal Perkotaan Gejala Involusi Gelombang Kedua). Jakarta : LP3S. 1994

[3] J.A. Naf. Street Vendors with Various Aspect of Problems(Pedagang Kaki Lima dengan Berbagai Segi dan Permasalahannya). Majalah Galang Vol 1 No 1. 1983

[4] I.S Ernawi.The Morfology-Transformation in the sustainable urban spatial planning (Morfologi-Transformasi dalam Ruang Perkotaan yang Berkelanjutan). Paper in Seminar on Tranformation in Urban Spaces at UNDIP Semarang. 2010

[5] Development Planning Agency at Sub-National Level (BAPPEDA) Local Development Planning Agency of Bandung, 2015

[6] R. Ramli, The Urban Informal Sector' Street Vendors(Sektor Informal Perkotaan: Pedagang Kaki Lima di Jakart)a. Jakarta: Ind-Hill Co. 1992

[7] M. Castells and A. Portes, World underneath; The origins, dynamics and effects of the informal economi in A.Portes, M. Casettello

[8] R. Bromley. Organization, regulation and exploitation of so called-urban informal sector. The Street trader in Cali, Colombia in urban sector. London: Pergamin, 1979 
[9] R.Setia Urban Informal Economy: A Case About Street Traders In Bandung City (Ekonomi Informal Perkotaan: Sebuah Kasus Tentang Pedagang Kaki Lima Di Kota Bandung), Bandung: Akatiga. 2008

[10] Kartono, dkk. Street vendrors (pedagang kaki lima). Bandung: Universitas Katholik Parahiyangan. 1980

[11] S.V. Sethuraman. The urban informal sector in developing countries: employment, poverty, and environment. Geneva : International Labour Office (ILO) 1981
[12] C.M. Firdausy. Model and Policy of Informal Sector Development of Street Traders. Development of the Informal Sector of Street-clothing in Urban Market (Model dan Kebijakan Pengembangan Sektor Informal Pedagang Kaki Lima. Pengembangan Sektor Informal Pedagang Kaki Lima di Perkotaan). LIPI. 1995 